\title{
PENINGKATAN HASIL BELAJAR TEMA KEGEMARANKU MELALUI MODEL PEMBELAJARAN DISCOVERY LEARNING
}

\author{
Elly Sukmanasa ${ }^{\text {a) }}$, Danti Damayanti ${ }^{\text {b) }}$ \\ a) Universitas Pakuan, Bogor, Indonesia \\ ${ }^{b)}$ SDN Ciheuleut, Bogor, Indonesia \\ e-mail korespondensi : ellysukmanasa@unpak.ac.id
}

diterima: 10 Nopember 2018; direvisi: 12 Desember 2019; disetujui: 04 Februari 2019

\begin{abstract}
The research with classroom action research approach is carried out in collaboration and cycles. It is conducted in class $1 \mathrm{~A}$ Ciheuleut 2 Elementary School, Bogor Timur with the aims of describing learning outcomes level of success in Tema 2 Kegemaranku, Sub-tema 4 Gemar Membaca Pembelajaran ke 3 through scientific approach by applying discovery learning model. The subjects of this study are a teacher with 31 students in the odd semester 2018/2019 school year. The first cycle result showed that the average value of learning outcomes of the students who achieved completeness is 16 students (48\%), while 15 students (32\%) have not. Meanwhile, In the second cycle there are 27 students (87\%) who achieved completeness, and 4 students (13\%) have not yet achieved it yet. In the first cycle learning process, the students changing behavior values were $48 \%$ which was considered good enough, and in the second cycle the average score is $80 \%$ with good category. From the results of this study it can be concluded that the application of discovery learning in Tema 2 Kegemaranku, Subtema 4 Gemar Membaca, Pembelajaran 3 in class 1A Ciheuleut 2 Elementary School, Bogor Timur improves the changes of students behavior.
\end{abstract}

Keywords: Discoveri Learning, Peserta Didik, Tema Kegemaranku

\section{PENDAHULUAN}

Proses pembelajaran yang dilakukan oleh peserta didik dalam mencapai hasil belajar tertentu di bawah bimbingan, arahan, dan motivasi guru. Pernyataan ini, memiliki arti bahwa pembelajaran bukanlah proses yang didominasi guru. peserta didik dituntut kreatif dalam melakukan sejumlah aktivitas sehingga Peserta Didik benarbenar membangun pengetahuannya secara mandiri. Pembelajaran dalam konteks Kurikulum 2013 diorientasikan untuk menghasilkan peserta didik yang produktif, kreatif, dan inovatif melalui penguatan sikap, keterampilan, dan pengetahuan yang terintegrasi.

Berdasarkan hasil observasi dengan guru kelas I (A) SD Negeri Ciheulet 2 Bogor Timur didapat permasalahan berkaitan dengan hasil belajar peserta didik. Permasalahan yang ditemukan yaitu peserta didik kesulitan dalam tema 2 kegemaranku. Menurut pemaparan guru kelas I-A dikatakan bahwa peserta didik kesulitan dalam mengenal abjad dan menyebutkan jumlah bilangan. Hal ini dibuktikan dengan data nilai ulangan harian peserta didik kelas I-A SD Negeri Ciheulet pada tema kegemaranku, sebelum dilakukan perbaikan nilai, dari 30 peserta didik, sebagian besar peserta didik belum mencapai nilai KKM (70) yaitu sekitar 68\% atau sekitar 21 orang peserta didik dan di atas KKM sekitar $32 \%$. Atau sekitar 9 orang peserta didik. Permasalahan tersebut diakibatkan beberapa faktor, yaitu: 1) Kurang variatifnya penerapan model pembelajaran. 2) Penggunaan media pembelajaran yang kurang tepat. 3) Dalam pelaksanaan pembelajaran terdapat beberapa peserta didik yang tidak fokus dalam mengikuti pembelajaran.

Merujuk pada permasalahan di atas, peneliti beranggapan perlu adanya penerapan model pembelajaran yang bisa memotivasi keaktifan peserta didik, kemandirian, dan keterlibatan langsung dalam proses pembelajaran sehingga pada akhirnya dapat memperbaiki dan meningkatkan hasil belajar peserta didik. Salah satunya model pembelajaran yang dapat diterapkan, yaitu model discovery learning. Model discovery learning efektif dalam membantu peserta didik untuk mendapatkan informasi dengan cara pemecahan masalah, sehingga peserta didik menemukan pemahaman baru. Hasil belajar dapat ditingkatkan dengan menerapkan model pembelajaran, salah satunya dengan model discovery learning. Seperti yang telah diteliti oleh Sri Hastuti [1], bahwa dengan penerapan model discovery learning dapat meningkatkan hasil belajar IPA peserta didik. Penelitian tentang penerapan model pembelajaran discovery learning ini juga dilakukan oleh Rosarina, Sudin dan Sujana [2] Ketertarikan dalam menerapkan model pembelajaran discovery learning ini juga mendapatkan perhatian dari beberapa peneliti lain, yaitu Irma Cintia, Kristin, dan Anugraheni [3] serta penelitian Setiawan dan Istiqomah [4]. Keempat penelitian tersebut memiliki kesamaan dengan penelitian yang akan dilakukan, yaitu meneliti tentang model pembelajaran discovery learning dan hasil belajar yang masih rendah. Temuan dari penelitian menunjukkan adanya perbaikan hasil belajar menjadi lebih meningkat. Dengan demikian dapat disimpulkan bahwa model pembelajaran discovery learning ini dapat memberikan peningkatan hasil belajar tidak hanya di kelas rendah namun dapat diterapkan juga pada kelas tinggi. Hal ini membuktikan bahwa model pembelajaran discovery learning akan mampu memberikan motivasi pada peseta didik dalam meningkatkan hasil belajarnya.

Uraian permasalahan dan temuan hasil penelitian dari beberapa peneliti di atas memberikan acuan atau dasar dalam memecahkan permasalahan yang terjadi di sekolah dasar Ciheulet. Permasalahan tersebut dapat dituangkan ke dalam judul "Penerapan Model Discovery Learning Untuk 
Meningkatkan Hasil Belajar Tema Kegemaranku" pada Peserta Didik kelas I SD Negeri Ciheulet 2 Kecamatan Bogor Timur Kota Bogor Semester Ganjil Tahun Pelajaran 2018/2019.

Berdasarkan latar belakang masalah di atas, maka pembatasan masalah pada penelitian ini dibatasi pada hasil belajar Peserta Didik yang belum mencapai KKM, yaitu $70 \%$. Tujuan penelitian ini untuk memperoleh jawaban dari pertanyaan penelitian yang telah dirumuskan. Secara rinci tujuan tersebut adalah untuk memperbaiki proses pembelajaran dan meningkatkan hasil belajar tema kegemaranku.pada Peserta Didik di kelas I SD Negeri Ciheuleut Kecamatan Bogor Timur Kota Bogor semester ganjil tahun pelajaran 2018/2019.

Hasil belajar merupakan perubahan-perubahan yang terjadi pada diri Peserta Didik, Susanto [5] menerangkan baik yang menyangkut aspek kognitif, afektif, dan psikomotor sebagai hasil dari kegiatan belajar. Kemudian Winkel dalam oleh Purwanto [6] menjelaskan hasil belajar adalah perubahan-perubahan yang mengakibatkan manusia berubah dalam sikap dan tingkah lakunya bahwa aspek perubahan itu mengacu pada tujuan pengajaran yang mencakup aspek kognitif, afektif, psikomotorik. Hasil belajar pada materi kelas satu diantaranya tema kegemaranku.

Tema kegemaranku merupakan tema kedua yang terdapat pada kelas 1 semester 1 . Pada tema ini terdapat empat subtema, diantaranya subtema 1 gemar beolah raga, subtema 2 gemar bernyanyi dan menari, subtema 3 gemar menggammbar, dan subtema 4 gemar membaca. Kegemaran dalam Kamus Besar Bahasa Indonesia berarti kesukaan,kesengan,atau sesuatu yang digemari. Pembelajaran yang dilakukan pada penelitian ini yaitu pembelajaran 5 pada subtema 1 gemar berolahraga dan pembelajaran 5 pada subtema 2 gemar bernyanyi dan menari.

Uraian di atas dapat disintesiskan bahwa hasil belajar merupakan pencapaian nilai Peserta Didik pada satu pertemuan dalam hal ini pada tema kegemaranku pembelajaran 2, terdiri bahasa Indoensia dan matematika. Pencapaian tersebut terdiri dari aspel pengetahuan, sikap, dan psikomotor atau keterampilan.

Hasil belajar dapat terjadi sesuai dengan tujuan apabila guru melakukann proses pembelajaran dengan melakukan inovasi seperti menerapkan metode dan model pembelajaran yng bervariasi. Salah satu model pembelajarn yng dapat diterapkan pada kurikulum 2013, yaitu discovery learning atau pembelajaran berbasis penemuan. Discovery learning menurut Cahyo dalam Rodiawati [7] metode pembelajaran discovery learning merupakan metode yang mengatur segala pengajaran sehingga peserta didik mendapatkan pengetahuan baru melalui metode penemuan yang ditemukan sendiri. Seorang guru memberikan ruang kepada Peserta Didiknya untuk dapat berdiri sendiri mendorong Peserta Didik untuk mandiri guna memperoleh pengetahuan baru. Selain itu, Menurut Johar dalam Burais [8] discovery learning terjadi ketika peserta didik bukan sebagai target informasi atau pemahaman konseptual melainkan peserta didik yang menemukannya secara independen dengan menggunakan material yang disediakan.

Penerapan discovery learning dikatakan Gultom [9] merupakan pembelajaran yang ingin merubah kondisi belajar yang pasif menjadi aktif dan kreatif. Mengubah pembelajaran yang teacher oriented ke student oriented. Merubah modus ekspository yang peserta didik hanya menerima informasi secara keseluruhan dari guru ke modus discovery peserta didik untuk menemukan informasi sendiri. Sementara itu Dina [10] menjelaskan bahwa keterlibatan secara langsung merupakan bagian dari keaktifan peserta didik dalam mengikuti kegiatan belajar -mengajar di kelas. Selain itu, pembelajaran dengan penemuan membantu Peserta Didik membentuk cara kerja bersama yang efektif, saling membagi informasi, serta mendengar dan menggunakan ide-ide orang lain.

Berdasarkan keluasan pengetahuan yang diperolehnya menurut Narayani [11] peserta didik lebih lanjut akan memiliki rasa percaya diri yang tinggi selama mengikuti proses pembelajaran. Rasa percaya diri merupakan hal penting dimiliki peserta didik agar mereka berani melakukan berbagai aktivitas belajar dan terbiasa dengan menanggung resiko pembelajaran.

Dengan demikian dapat diartikan bahwa model discovery learning dapat memberikan kesempatan kepada Peserta Didik untuk belajar lebih aktif, kreatif dan lebih menyenangkan. Peserta Didik dapat menemukan sendiri jawaban melalui percobaan yang dilakukannya tanpa harus selalu dibantu guru.

\section{METODE PENELITIAN}

Penelitian ini dengan pendekatan penelitian kelas melalui rancangan penelitian sebagai berikut:

1. Tempat Penelitian

Penelitian ini dilaksanakan di kelas 1 SD Negeri Ciheleut 2 Kecamatan Bogor Timur Kota Bogor Tahun 2018/2019.

2. Waktu Penelitian

Penelitian dilakukan pada semester gasal/ganjil tahun pelajaran 2018/2019, yaitu pada bulan September 2018.

3. Subjek Penelitian

Subjek dari penelitian ini adalah Peserta Didik kelas 1 SD Negeri Ciheleut 2 Kecamatan Bogor Timur Kota Bogor yang berjumlah 31 orang.

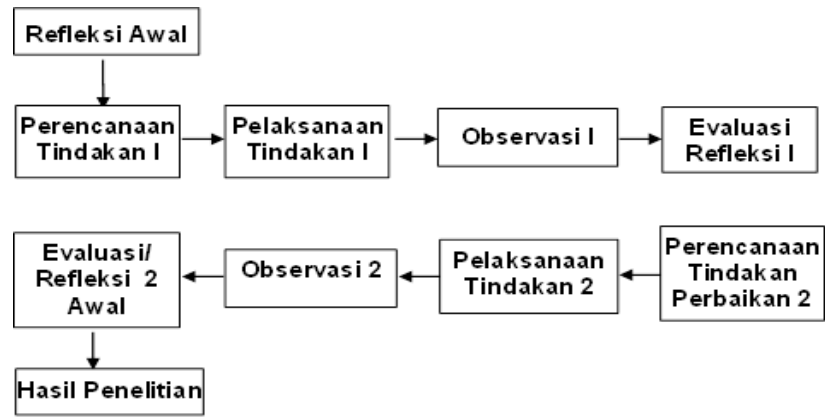


Gambar 1. Bagan desain PTK Model Modifikasi Depdiknas Dari Model Kemmis dan Taggart

Gambar di atas menunjukkan pelaksanaan penelitian yang diawali dengan melakukan kegiatan prapenelitian atau mencari pokok permasalahan kemudian merencanakan tindakan dengan mempersiapkan silabus, Rencana Pelaksanaan Pembelajaran (RPP), bahan ajar, media pembelajaran, dan lain-lain, kemudian melaksanakan tindakan sesuai perencanaan, pada saat pelaksanaan tindakan dilakukan observasi atau pengamatan oleh kolaborator terhadap proses pelaksanaan pembelajaran kemudian melakukan refleksi hingga ditemukan hasil dari penelitian.Teknik pengumpulan data yaitu: Observasi yang meliputi pelaksanaan pembelajaran, observasi sikap, observasi keterampilan dan hasil belajar yang dinilai oleh tim kolaborator dengan menggunakan instrumen penilaian. Teknik pengumpulan data selanjutnya adalah penilaian dan yang terakhir adalah studi dokumentasi.

Instrumen pengumpulan data meliputi: 1) Instrumen pelaksanaan proses pembelajaran didalam kelas., 2) Lembar observasi perubahan sikap (kerjasama, disiplin dan tanggung jawab). 3) Lembar observasi perubahan keterampilan mendemonstrasikan, berdiskusi, dan keterampilan penggunaan bahasa yang tepat

\section{Teknik Analisis Data}

Analisis data hasil penelitian skripsi yaitu dengan penerapan rumusan statistik deskriptif dengan melalui tahapan sebagai berikut:

a. Pengumpulan Data ; Dalam tahap pengumpulan data ini, peneliti mengumpulkan data yang diperoleh peneliti dari hasil penelitian pelaksanaan pembelajaran di kelas, observasi dalam aktivitas Peserta Didik dilakukan secara berkelompok.

b. Reduksi Data; Dalam tahap ini, peneliti memilih dan memilah data yang benar-benar relevan tetapi data yang tidak relevan tidak akan dibuang.

c. Pemaparan Data ; Dalam tahap ini, peneliti memaparkan data-data yang telah terseleksi dalam bentuk atau urutan jenis data:

1) Data hasil penilaian pelaksanaan pembelajaran di kelas; a) Tabulasi, menghitung rata-rata serta persentase. b) Menggambar histogram tanpa tabel distribusi frekuensi (TDF). c) Analisis dan interpretasi.

2) Data hasil observasi perubahan sikap atau prilaku Peserta Didik; a) Tabulasi, dan menghitung ratarata serta presentase data kelompok belajar, serta menggambarkan histogram dengan semua kelompok pembelajaran. b) Menyusun Tabel Distribusi Frekuensi dengan menggunakan aturan Sturgess. c) Menggambar diagram histogram. d) Analisis data dan interpretasi data.

3) Data hasil belajar (pengetahuan dan keterampilan);

a) Menghitung tabulasi data atau nilai hasil belajar.

b) Menghitung rata-rata dan presentase.

c) Menyusun tabel ketuntasan hasil belajar.

d) Menyusun tabel distribusi frekuensi (TDF) (n >
1) dengan menggunakan aturan Sturgess, melalui langkah-langkah berikut:

e) Menentukan nilai rentang (range)

a. Nilai rentang diperoleh dari nilai yang terbesar dikurangi nilai yang terkecil.

b. Rentang = Nilai terbesar-Nilai terkecil

f) Menentukan banyak kelas

a. $K=1+3,3 \log n$

b. Yaitu dimana nilai $\mathrm{n}=$ jumlah Peserta Didik atau responden

g) Panjang kelas

a. $(P)(P)=\frac{R R}{K K}$

h) Menyusun tabel distribusi frekuensi (TDF) yang terdiri menggunakan tabel konversi.

Keberhasilan dari sebuah penelitian tindakan harus mencapai target standar nilai tertentu. Pada proses pelaksanaan pembelajaran, indikator keberhasilan penelitian yaitu dapat mencapai nilai minimal $85 \%$. Indikator keberhasilan penelitian pada aktivitas perubahan sikap dapat mencapai nilai minimal 81. Indikator keberhasilan penelitian pada aktivitas perubahan Perilaku Peserta Didik dapat mencapai nilai minimal 81 dan indikator keberhasilan pada ketuntasan hasil belajar Peserta Didik secara klasikal yaitu $85 \%$ dengan mencapai nilai KKM mata pelajaran Bahasa Indonesia yang telah ditetapkan yaitu 72 .

\section{HASIL DAN PEMBAHASAN}

Penelitian kurikulum 2013 dilaksanakan pada Peserta Didik kelas 1 A SDN Ciheuleut 2 Tahun Pelajaran 2018/2019, subyek yang diteliti adalah sebanyak 31 Peserta Didik yang terdiri dari 13 Peserta Didik perempuan dan 18 Peserta Didik laki-laki. Penelitian dilakukan untuk meningkatkan hasil belajar Peserta Didik pada tema Kegemaranku melalui model Discovery Learning.

Hasil penelitian yang didapatkan dengan pengumpulan data pada kegiatan pelaksanaan pembelajaran siklus I dan siklus II dihitung hingga ditemukan nilai hasil pencapaian indikator keberhasilan penelitian dengan ketuntasan hasil belajar secara klasikal minimal $85 \%$.

Penelitian ini dilakukan dalam rangka memperbaiki proses pembelajaran perilaku Peserta Didik, serta hasil belajar Peserta Didik pada tema kegemaaranku. Adapun deskripsi data hasil prapenelitian adalah sebagai berikut:

1. Deskripsi Data Hasil Penelitian Siklus I

Ketuntasan hasil belajar Peserta Didik menunjukkan bahwa Peserta Didik yang telah mencapai ketuntasan hasil belajar pada siklus I berjumlah 16 Peserta Didik atau 52\%. Sedangkan 15 Peserta Didik lainnya atau 48\% masih belum mencapai ketuntasan hasil belajar. Pada proses pembelajaran yang dilaksanakan pada siklus 1 memperoleh nilai 78,5. Perilaku perubahan sikap Peserta Didik yang tampak memperoleh nilai rata-rata $48 \%$. Data hasil penelitian pada siklus 1 yang telah didapat kemudian dilakukan refleksi untuk memperbaiki kekurangan yang terjadi pada siklus II untuk diterapkan pada penelitian selanjutnya. 
2. Deskripsi Data Hasil Penelitian Siklus II Ketuntasan hasil belajar

Ketuntasan hasil belajar Peserta Didik menunjukkan bahwa Peserta Didik yang telah mencapai ketuntasan hasil belajar pada siklus II berjumlah 27 Peserta Didik atau $87 \%$. Sedangkan 4 Peserta Didik lainnya atau $13 \%$ masih belum mencapai ketuntasan hasil belajar. Perolehan nilai rata-rata hasil belajar pada siklus II yaitu 82,50 dan nilai tersebut sudah mencapai nilai KKM yang ditentukan sebesar 72. Pada proses pembelajaran yang dilaksanakan pada siklus II memperoleh nilai 84,75 Perilaku perubahan sikap Peserta Didik yang Tampak memperoleh nilai rata-rata $80 \%$.

Peningkatan hasil pelaksanaan pembelajaran yang dilakukan pada siklus I dan siklus II, maka dibuatlah rekapitulasi hasil penelitian dan rekapitulasi tingkat kesukaran butir soal seperti tampak pada tabel .1

Tabel 1. Rekapitulasi Hasil Penelitian Siklus I dan Siklus II

\begin{tabular}{|c|c|c|c|c|c|c|}
\hline \multirow{2}{*}{$\begin{array}{c}\text { Aspek yang } \\
\text { diamati }\end{array}$} & \multicolumn{4}{|c|}{ Hasil Siklus } & \multirow{2}{*}{ Indikator } & \multirow{2}{*}{ Ket. } \\
\cline { 2 - 5 } & \multicolumn{2}{|c|}{ Siklus I } & \multicolumn{2}{c|}{ Siklus II } & \\
\cline { 2 - 5 } & Ketuntasan & Makna & Ketuntasan & Makna & & Meningkat \\
\hline $\begin{array}{c}\text { Perbaikan } \\
\text { proses } \\
\text { pembelajaran }\end{array}$ & 78,5 & Baik & 84,75 & $\begin{array}{c}\text { Sangat } \\
\text { Baik }\end{array}$ & 81 & Meningkat \\
\hline $\begin{array}{c}\text { Hasil belajar } \\
\text { aspek sikap } \\
\text { sosial }\end{array}$ & $48 \%$ & Cukup & $80 \%$ & Baik & 81 & Meningkat \\
\hline $\begin{array}{c}\text { Ketuntasan } \\
\text { hasil belajar } \\
\text { aspek } \\
\text { pengetahuan }\end{array}$ & $48 \%$ & $\begin{array}{c}\text { Belum } \\
\text { Tuntas }\end{array}$ & $87 \%$ & Tuntas & $80 \%$ & \\
\hline
\end{tabular}

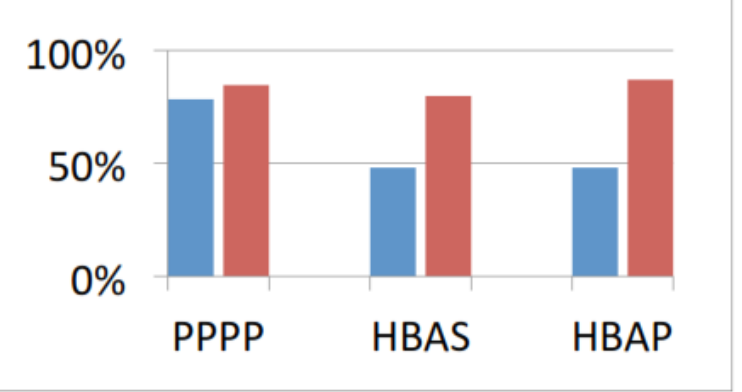

Gambar 1. Diagram Histogram Hasil Penelitian Siklus I dan Siklus II

Keterangan:

PPPP : Penilaian Perbaikan Proses Pembelajaran

HBAS : Hasil Belajar Aspek Sikap

HBAP : Hasil Belajar Aspek Pengetahuan

Penelitian dengan model pembelajaran discovery learning ini dapat dikatakan berhasil karena adanya peningkatan dari siklus 1 ke siklus 2 . Hal tersebut didukung oleh Hamzah [12] yang menyatakan bahwa hasil belajar merupakan perubahan perilaku yang relatif menetap dalam diri seseorang sebagai akibat dari interaksi seseorang dengan lingkungannya. Hasil belajar memiliki beberapa ranah atau kategori dan secara umum merujuk kepada aspek pengetahuan, sikap, dan keterampilan.
Hasil penelitian tersebut dapat juga dipengaruhi oleh beberapa faktor seperti halnya yang diungkapkan oleh Susanto [5] mengungkapkan bahwa faktor yang mempengaruhi hasil belajar dikelompokkan menjadi dua, yaitu faktor dari dalam diri Peserta Didik sendiri (Intern) yang meliputi kemampuan berpikir Peserta Didik, motivasi Peserta Didik dalam menempuh pembelajaran, minat tehadap belajar, dan kesiapan Peserta Didik baik jasmani maupun rohani, sedangkan faktor dari luar diri Peserta Didik (ekstern) yang dapat mempengaruhinya yaitu meliputi sarana prasarana, kompetensi guru, kreativitas guru, sumber - sumber belajar, metode, serta dukungan lingkungan keluarga, dan masyarakat.

Pembahasan di atas dapat disimpulkan bahwa penerapan model Poblem Based Learning dapat memperbaiki proses pembelajaran di kelas dan meningkatkan hasil belajar Peserta Didik pada tema kegemaranku baik hasil belajar aspek sikap, hasil belajar aspek pengetahuan dan hasil belajar aspek. Penelitian lain yang meneliti tentang model pembelajaran ini dilakukan oleh A.Supriyadi [13] menemukan hasil obsevasi diketahui bahwa sebagian besar hasil belajar peserta didik dalam pembelajaran bentuk daun dan fungsinya dengan metode discovery learning pada peserta didik kelas IV pada siklus I hanya mampu mencapai $65,55 \%$ dari aktivitas positif dan terjadi peningkatan setelah siklus II menjadi sebesar 75,55\%. 3) penerapan metode discovery learning pada pembelajaran bentuk daun dan fungsinya pada peserta didik kelas IV di Sekolah Dasar Negeri 03 Sungai Ambawang diketahui sudah sangat efektif dan tepat hal ini ditunjukan dari rata-rata nilai evaluasi belajar peserta didik pada siklus I adalah sebesar 78,72 dan terjadi peningkatan setelah adanya perbaikan pembelajaran pada siklus II menjadi 97,76. Kondisi ini juga ditemukan pada penelitian Ina Azariya Yupita [14] ditemukan hasil bahwa pembelajaran dengan menerapkan model discovery dapat meningkatkan aktivitas guru dan peserta didik serta hasil belajar peserta didik. Hal ini terbukti dari hasil pengamatan yang diperoleh pada tiap siklusnya. pada siklus i, aktivitas guru mencapai $78,57 \%$, aktivitas peserta didik $66,07 \%$, dan hasil belajar peserta didik $63,89 \%$. Pada siklus II, aktivitas guru mencapai $83,9 \%$, aktivitas peserta didik $78,6 \%$, dan hasil belajar peserta didik $77,77 \%$. Pada siklus III, aktivitas guru mencapai $91,07 \%$, aktivitas peserta didik $87,5 \%$, dan hasil belajar peserta didik $94,44 \%$. Artinya pembelajaran dengan model discovery learning dapat meingkatkan aktivitas belajar dan hasil belajar peserta didik. Penerapan model discovery learning juga tidak hanya dapat meningkatkan hasil belajar namun dapat meningkatkan aspek lain seperti rasa percaya diri. Hal ini ditemukan pada penelitian yang dilakukan Erna Eryani [15] bahwa penerapan model Discovery learning pada Pada sub tema tubuhku dapat meningkatka ketreampilan berkomunikiasi dan rasa percaya diri dan rasa percaya diri peserta didik di kelas I SDN 16 Babakan Ciparay Kota Bandung

\section{SIMPULAN}

Berdasarkan pembahasan hasil penelitian, dapat disimpulkan bahwa: Perbaikan Hasil Belajar tema 
Kegemaranku melalui model pembelajaran Discovery Learning dapat memperbaiki proses pembelajaran dan meningkatkan hasil belajar Peserta Didik kelas 1A SD Negeri Ciheulet 2 Kota Bogor Semester Ganjil Tahun Pelajaran 2018/2019.

\section{REFERENSI}

[1] Sri Hastuti. 2017. Penerapan Model Pembelajaran Penemuan (Discovery Learning) Untuk Meningkatkan Hasil Belajar IPA. Pada Peserta Didik Kelas IV SD Negeri 1 Rejosari Gondangrejo Karanganyar Tahun Pelajaran 2016/2017. Jurnal Karya Ilmiah MahaPeserta Didik Progdi Pendidikan Guru Sekolah Dasar FKIP. Vol.2. No.2.

[2] Rosarina, Gina, Sudin, Ali Dan Sujana, Atep. 2016. Penerapan Model Discovery Learning Untuk Meningkatkan Hasil Belajar Siswa Pada Materi Perubahan Wujud Benda. Jurnal Pena Ilmiah: Vol. 1, No. 1

[3] Irma Cintia, Nichen, Kristin, Firosalia \& Anugraheni, Indri. 2018. Penerapan Model Pembelajaran Discover Learning Untuk Meningkatkan Kemampuan Berpikir Kreatif dan Hasil Belajar Siswa. PERSPEKTIF Ilmu Pendidikan - Vol. 32 No. 1 April 2018.

[4] Setiawan, Veri Dan Istiqomah. 2016. Penerapan Model Pembelajaran Discovery Learning Untuk Meningkatkan Minat Dan Prestasi Belajar. Prosiding Seminar Nasional Etnomatnesia.

[5] Susanto, Ahmad. 2013.Teori Belajar \& Pembelajaran di Sekolah Dasar. Jakarta: Prenadamedia Group

[6] Purwanto. 2011. Evaluasi Hasil Belajar. Yogyakarta: Pustaka Pelajar.

[7] Rodiawati, LIlis. 2015. Perbandingan Koneksi Matematika Peserta Didik Antara yang Menggunakan Model Pembelajaran Discovery Learning Dengan Model Pembelajaran Knisley. Dalam Jurnal Euclid, ISSN 2355-1712, vol.3, No.2, pp. 549

[8] Burais, Listika, dkk. Peningkatan Kemampuan Penalaran Matematis Peserta Didik Melalui Model Discovery Learning. Dalam Jurnal Didaktik Matematika ISSN: 2355-4185 77, Vol. 3, No.1, Tahun 2016, pp 80

[9] Gultom, Syawal. 2014. Materi Pelatihan Guru Implementasi Kurikulum 2013 Tahun Ajaran 2014/2015. (Jakarta: Badan Pengembangan Sumber Daya Manusia Pendidikan dan Kebudayaan dan Penjaminan Mutu Pendidikan Kemendikbud, 2014), hal 37

[10] Dina, Arifatud. dkk. 2015. Implementasi Kurikulum 2013 Pada Perangkat Pembelajaran Model Discovery Learning Pendekatan Scientific Terhadap Kemampuan Komunikasi Matematis Materi Geometri SMK. Dalam JKPM, ISSN: 2339-2444, Vol.2 No.1, Tahun 2015, pp.24

[11] Narayani, Dsk. Pt. Rimang, dkk. 2015. Analisis
Proses Pembelajaran Matematika Menurut Pendekatan Saintifik Dan Dampaknya Terhadap Hasil Belajar Peserta Didik Kelas 5. Dalam e-Journal PGSD Universitas Pendidikan Ganesha Jurusan PGSD Volume. 3 No.1, Tahun 2015

[12] Hamzah, Uno. 2008. Teori Motivasi dan Pengukurannya. Jakarta: Bumi Aksara.

[13] Ina Azariya Yupita. 2013. Penerapan Model Pembelajaran Discovery Untuk Meningkatkan Hasil Belajar IPS Di Sekolah Dasar. Jurnal Pendidikan Guru Sekolah Dasar. Vol.1 No. 2.

[14] A.Supriyadi. 2013. Peningkatan Hasil Belajar Metode Discovery Learning Pembelajaran IPA Kelas IV SDN 03 Sungai Ambawang Kubu Raya. Jurnal Pendidikan dan Pembelajaran. Vol. 2 No. 8

[15] Erna Eryani. 2016. Penerapan Model Pembelajaran Discovery Learning Untuk Meningkatkan Keterampilan Berkomunikasi dan Sikap Percaya Diri Pada Tema Diri Sendiri Sub. Tema Tubuhku Peserta Didik Kelas 1 Sdn 16 Babakan Ciparay Kota Bandung. Skripsi(S1) Thesis, Fkip Unpas. http://repository.unpas.ac.id/5939/. Diakses tanggal 20-10-2018 